\title{
Pengembangan Bahan Ajar Bahasa Indonesia untuk Penutur Asing (BIPA) berdasarkan Hasil Analisis Kebutuhan Belajar
}

\author{
Imam Suyitno
}

\begin{abstract}
Teaching Indonesian for Foreign Learners or Indonesian as a Foreign Language (IFL) is different from teaching Indonesian as a first language. The differences are due to the characteristics of the learners. IFL learners generally are adults who have language and cultural background and learning style different from those Indonesian learners have. These differences demand IFL teachers and instructors to prepare teaching-learning materials and the activities of the teaching-learning process in the classroom that are relevant to the learners' needs. Understanding the entry level behavior of the learners, the teaching materials, the teaching-learning approach, and the evalution process is of crucial importance in order to fulfill their needs. Learning needs analysis of IFL learners is also a prerequisite to developing adequate teaching-learning materials of IFL.
\end{abstract}

KEYWORDS teaching-learning process, teaching-learning materials, teaching-learning approach

Pelajar BIPA adalah pelajar asing yang memiliki latar belakang bahasa dan budaya berbeda dengan budaya bahasa yang dipelajarinya. Perbedaan bahasa dan budaya tersebut memiliki konsekuensi pada pemilihan materi bahasa Indonesia yang akan diajarkan kepada mereka karena pemerolehan bahasa kedua, termasuk bahasa Indonesia untuk penutur asing, dipengaruhi secara kuat oleh bahasa pertama (Ellis 1986:19). Lebih lanjut, Lee mengatakan bahwa satu-satunya penyebab kesulitan dan kesalahan dalam belajar bahasa kedua atau bahasa asing adalah pengaruh bahasa pertama pelajar (Ellis 1986:23).

Tingkat kemampuan pelajar BIPA berbeda-beda, mulai pelajar dengan tingkat pemula hingga dengan pelajar tingkat lanjut. Berdasarkan tingkatan kemampuan pelajar BIPA tersebut, muncul berbagai macam materi BIPA. Pada materi tersebut tercatat beberapa penulis buku, baik penulis asing maupun penulis Indonesia, yang menulis bahasa Indonesia untuk penutur asing. Tujuan yang hendak mereka capai ialah mempermudah pelajar menguasai bahasa Indonesia. Walaupun demikian, terdapat banyak variasi yang ditemukan baik dalam hal pendekatan, teknik pengajaran, bahan ajar 
maupun urutannya. Masing-masing penyusun buku teks tersebut berasumsi bahwa buku yang disusunnyalah yang paling efisien dan efektif untuk pelajaran bahasa Indonesia.

Pelajar BIPA pada umumnya adalah orang dewasa. Yang dimaksud dengan orang dewasa di sini adalah mereka yang berusia 17 tahun ke atas. Oleh karena itu, Sugino (1995:6) menjelaskan bahwa ada beberapa sifat yang harus diperhatikan dalam pemilihan materi BIPA. Yang pertama, orang dewasa sudah memiliki cukup banyak pengetahuan dan wawasan, sehingga kebutuhan mereka juga kebutuhan orang dewasa bukan lagi kebutuhan anak-anak. Oleh karena itu, topik aktual yang ingin mereka pelajari adalah topik umum seperti misalnya, masalah lingkungan, hubungan antarmanusia, peristiwa dunia, dan sebagainya. Yang kedua, bahwa orang asing (orang Barat) suka mengekpresikan diri mereka, mempresentasikan sesuatu, mengemukakan pendapat, sehingga tugas di luar kelas atau membuat proyek sederhana akan sangat menarik. Terakhir, untuk mengakomodasi minat dan kebutuhan yang mungkin berbeda dari yang satu dengan yang lain perlu disiapkan materi yang bervariasi.

Gambaran tentang wujud BIPA dapat ditinjau dari segi tujuan belajar BIPA. Tujuan pembelajaran BIPA memiliki kaitan yang erat dengan masalah pemenuhan kebutuhan. Sejalan dengan masalah ini, Mackey dan Mountford (Sofyan 1983) menjelaskan bahwa ada tiga kebutuhan yang mendorong seseorang belajar bahasa, yakni (1) kebutuhan akan pekerjaan, (2) kebutuhan program latihan kejuruan, dan (3) kebutuhan untuk belajar. Sesuai dengan pendapat itu, Hoed (1995) menyatakan bahwa program BIPA bertujuan untuk (1) mengikuti kuliah di perguruan tinggi Indonesia, (2) membaca buku dan surat kabar guna keperluan penelitian, dan (3) berkomunikasi secara lisan dalam kehidupan sehari-hari di Indonesia. Ketiga tujuan itu masing-masing masih dapat diperluas lagi menjadi beberapa tujuan khusus, misalnya, untuk mengikuti kuliah di perguruan tinggi di Indonesia memerlukan pengetahuan bahasa Indonesia sesuai dengan bidang ilmu yang diikuti (ilmu sosial, ilmu teknik, ekonomi, dan sebagainya). Begitu pula untuk keperluan penelitian tergantung dari bidang apa yang akan diteliti. Untuk belajar bahasa Indonesia lisan guna keperluan komunikasi dengan penduduk diperlukan pula pengkhususan, misalnya komunikasi formal atau informal.

Penekanan pengajaran BIPA perlu dibedakan sesuai dengan tujuan yang akan dicapai. Soewandi (1994:4-6) menjelaskan bahwa tujuan pengajaran BIPA yang sangat menonjol adalah (1) untuk berkomunikasi keseharian dengan penutur bahasa Indonesia (tujuan umum), dan (2) untuk menggali kebudayaan Indonesia dengan segala aspeknya (tujuan khusus). Tujuan yang pertama, penekanannya pada penguasaan bahasa sehari-hari yang dapat dipakai untuk kepentingan praktis, seperti menyapa, menawar, menolak, mempersilakan, mengucapkan terima kasih, minta izin, mengajak, mengeluh, memuji, memperkenalkan, berpamitan, dan sebagainya. Ciri khas bahasa untuk kepentingan ini adalah lebih sering (1) dipergunakannya bentuk- 
bentuk kata yang nonformal, (2) dipergunakannya kosakata yang tidak baku, (3) dihilangkannya imbuhan, dan (4) digunakannya susunan kalimat yang sederhana Adapun ciri bahasa untuk tujuan kedua adalah penggunaan (1) bentuk kata baku, (2) kosakata teknis, (3) imbuhan secara lengkap, (4) kaidah penulisan yang benar, dan (5) susunan kalimat yang baku.

Dalam pengajaran BIPA, yang perlu mendapatkan perhatian adalah para pelajarnya sehingga pembelajaran berorientasi pada siswa sebagai pusat (learner centered) (Robinson 1980:10). Munby (1980:2) menjelaskan bahwa pemusatan perhatian pada siswa dalam pembelajaran bahasa merupakan ciri yang membedakan pengajaran bahasa untuk penutur asing dengan pengajaran bahasa untuk penutur asli (yang membedakan BIPA dari yang bukan BIPA). Oleh karena itu, materi pembelajaran harus berupa materi yang fungsional.

Pembelajaran BIPA memiliki karakteristik dan norma pedagogik yang berbeda dengan pembelajaran bahasa Indonesia pada penutur asli. Perbedaan tersebut terjadi karena (a) pelajar BIPA pada umumnya telah memiliki jangkauan dan target hasil pembelajaran secara tegas, (b) dilihat dari tingkat pendidikannya, pada umumnya pelajar BIPA adalah orang-orang terpelajar, (c) para pelajar BIPA memiliki gaya belajar yang khas dan kadang-kadang didominasi oleh latar belakang budaya, (d) sebagian besar pelajar BIPA memiliki minat, dan motivasi yang tinggi terhadap bahasa Indonesia, (e) para pelajar BIPA memiliki latar belakang keilmuan yang berbeda-beda, dan (f) karena perbedaan sistem bahasa, menyebabkan pelajar BIPA banyak menghadapi kesulitan terutama dalam masalah pelafalan dan penulisan (Suyitno 2000).

Pemahaman terhadap karakteristik pelajar asing diperlukan, terutama dalam upaya memilih dan mengembangkan bahan pembelajaran BIPA. Untuk itulah pembelajaran BIPA ditentukan oleh berbagai unsur yang masingmasing memiliki batasan fungsi dan peran di dalam mewujudkan tujuan yang telah ditetapkan. Unsur-unsur yang terlibat dalam proses pembelajaran tersebut, antara lain tujuan, materi, prosedur didaktik (metode/teknik), media, evaluasi, siswa(pelajar), guru (tutor/pamong), dan pengelolaan kelas.

Sebagai sebuah sistem proses, optimalisasi pembelajaran BIPA bergantung pada ketuntasan di dalam pengelolaan keseluruhan unsurnya, baik secara bebas maupun secara simultan. Pengelolaan tersebut harus disertai dengan pola dan langkah yang sistematis dengan tetap memperhatikan dan mempertimbangkan tujuan sebagai target dan tuntutannya. Oleh karena itu, diperlukan sejumlah pola dan langkah yang jelas dan terarah agar dapat mempercepat pencapaian tujuan pembelajaran dan pengimplementasian kualitas isi dan muatan kompetensi pembelajaran. Upaya untuk mengelola materi pembelajaran yang sedemikian rupa tidaklah mudah. Hal itu memerlukan sejumlah wawasan, keterampilan, dan kiat khusus, karena pengelolaan materi pembelajaran BIPA berkaitan dengan cara memilih, memilah, mengembangkan, dan mengemasnya secara proposional dan 
fungsional.

Materi pembelajaran BIPA pada hakikatnya adalah sarana yang digunakan untuk membelajarkan pelajar BIPA yang secara langsung digunakan sebagai bahan belajar untuk mencapai tujuan pembelajaran yang telah ditetapkan. Secara sederhana, materi pembelajaran dapat diartikan sebagai bahan yang digunakan untuk belajar dan yang membantu pencapaian tujuan pembelajaran, di tempat pelajar dituntut melakukan sesuatu terhadapnya dengan jenis perilaku tertentu.

Berdasarkan kekhususan ciri dalam proses pembelajaran BIPA, persoalan yang harus dijawab adalah bagaimana mengarahkan para pelajar asing agar termotivasi untuk belajar bahasa Indonesia sesuai dengan minat mereka. Padahal, hingga saat ini masih banyak perselisihan tentang bagaimana mengajarkan bahasa asing (termasuk bahasa Indonesia), baik yang berkaitan dengan alat-alat untuk mencapai tujuan, materi yang semestinya diajarkan, maupun metode pembelajarannya (Wojowasito 1976:1). Salah satu contoh permasalahan tersebut, sebagaimana dikemukakan oleh Toda dan Sinaga yang menyatakan bahwa dalam menentukan pilihan metode pembelajaran BIPA, tantangan pertama yang akan dihadapi adalah menentukan pilihan yang tepat untuk diikuti dalam kaitannya dengan konsep dasar dan saransaran pembelajaran bahasa yang dikemukakan oleh para ahli.

Untuk mengatasi permasalahan tersebut dan mempertahankan motivasi belajar pelajar asing, diperlukan upaya yang sungguh-sungguh dalam menciptakan perangkat pembelajaran yang sesuai dengan kebutuhan mereka. Hal itu berimplikasi pada, antara lain, upaya penyusunan program pembelajaran, pemilihan metode pembelajaran, pengadaan bahan ajar, penyelenggaraan evaluasi, penyiapan tenaga pengajar, pengadaan media, dan sumber belajar dan sebagainya yang sesuai dengan kebutuhan pelajar. Upaya awal yang perlu dilakukan untuk mengembangkan perangkat pembelajaran yang sesuai dengan kebutuhan pelajar BIPA adalah melakukan analisis kebutuhan belajar pelajar BIPA. Melalui analisis kebutuhan belajar tersebut akan diketahui kemampuan awal pelajar BIPA, tujuan belajar BIPA, bidang keahlian yang dimiliki pelajar BIPA, strategi dan gaya belajar pelajar BIPA, pengalaman belajar pelajar BIPA, dan minat dan motivasi belajar BIPA, dan sebagainya. Dengan pemahaman tersebut, dapat disusun dan dikembangkan bahan pembelajaran BIPA yang sesuai dengan kondisi pelajar.

\section{Metode Penelitian}

Penelitian ini termasuk penelitian pengembangan. Dalam penelitian ini, model pengembangan yang digunakan adalah model prosedural dengan mengadaptasi model rancangan sistem pembelajaran yang ditawarkan oleh Dick dan Carey (1978). Dalam pengembangan bahan ajar, diawali dengan pengenalan tujuan pembelajaran yang difokuskan pada analisis kebutuhan belajar dengan upaya pemahaman perilaku awal dan ciri pelajar asing. Untuk melakukan analisis kebutuhan belajar tersebut digunakan acuan yang 
ditawarkan oleh Hutchinson dan Waters (1989).

Setelah memahami perilaku awal pelajar asing, langkah selanjutnya dalam analisis kebutuhan adalah analisis domain (Spradley 1979) dengan tujuan untuk memetakan ranah, taksonomi, dan materi pembelajaran yang sesuai dengan hasil analisis kebutuhan belajar pelajar asing. Berdasarkan hasil pemetaan tersebut, disusunlah model rancangan bahan pembelajaran BIPA yang didasarkan pada kebutuhan belajar pelajar asing. Langkah selanjutnya, berdasarkan pada rancangan program tersebut, dikembangkan materi ajar BIPA. Dalam pengembangan materi ajar BIPA, peneliti mempertimbangkan beberapa kriteria sebagai berikut, yakni (1) kualitas produk, yang meliputi (a) kedalaman, keluasan, variasi, dan kreativitas isi, (b) organisasi, dan kelengkapan materi, (c) bahasa, dan (d) gaya, (2) efektivitas produk, yang meliputi kemampuan untuk (a) pencapaian tujuan, dan (b) pemenuhan kebutuhan belajar para pelajar, (3) efisiensi produk, yang meliputi efisiensi dari segi waktu, tenaga, dan biaya, (4) fisibilitas produk, yang memungkinkan dapat digunakan berdasarkan kompetensi guru dan pelajar asing.

Prosedur yang ditempuh dalam pengembangan bahan ajar BIPA berdasarkan hasil analisis kebutuhan belajar pelajar asing adalah (a) memahami model rancangan dan teori yang dikemukakan oleh Dick dan Carey (1978), Hutchinson dan Walters (1989), dan Munby (1980) untuk pengembangan model perangkat pembelajaran, (b) memantapkan model perangkat pembelajaran BIPA berdasarkan hasil analisis kebutuhan belajar pelajar asing, (c) melakukan analisis kebutuhan belajar pelajar asing, dengan upaya menjaring data selengkap mungkin tentang perilaku awal dan ciri pelajar asing, (d) melakukan analisis domain untuk memetakan ranah, taksonomi, dan materi pembelajaran yang sesuai dengan kebutuhan belajar pelajar asing, (e) mengembangkan model rancangan bahan pembelajaran BIPA berdasarkan hasil pemetaan ranah, taksonomi, dan materi pembelajaran, (f) melakukan triangulasi model rancangan bahan pembelajaran BIPA, (g) merevisi model rancangan bahan pembelajaran BIPA, $(\mathrm{h})$ mengembangkan draft bahan ajar untuk pembelajaran BIPA, (i) melakukan uji coba bahan ajar melalui uji ahli, uji guru dan tutor BIPA, dan uji lapangan (pelajar asing), (j) melakukan revisi model bahan ajar BIPA, (k) menyajikan model bahan ajar BIPA berdasarkan hasil analisis kebutuhan belajar pelajar asing.

Subjek penelitian ini dibedakan menjadi dua macam, yakni (1) subjek yang digunakan untuk penjaringan data dalam analisis kebutuhan belajar pelajar asing dan (2) subjek yang digunakan untuk triangulasi dan uji coba produk. Untuk menjaring data tentang kebutuhan belajar para pelajar asing, yang dijadikan subjek penelitian adalah pelajar asing yang sedang belajar BIPA serta para guru dan tutor BIPA. Dalam hal ini, dipilih pelajar asing dan para tutor serta pengajar BIPA yang ada di Malang. Adapun, untuk triangulasi dan uji coba produk, yang dijadikan subjek penelitian adalah kelompok ahli dan para guru dan tutor BIPA yang sudah berpengalaman. 
Data penelitian ini meliputi (1) data verbal tentang perilaku awal dan ciri pelajar asing yang bersumber dari (a) catatan hasil observasi dan hasil wawancara dengan pelajar asing, (b) catatan observasi dan wawancara dengan pengajar dan tutor BIPA, dan (c) dokumen yang berisi informasi pelajar asing, (2) data verbal tentang hasil pemetaan domain pembelajaran BIPA, yang berupa topik, materi belajar, pendekatan pembelajaran, teknik pembelajaran, dan pelaksanaan evaluasi pembelajaran yang bersumber dari bahan-bahan tertulis, dan (3) data verbal hasil triangulasi dan uji coba produk yang berupa saran, kritik, komentar kelompok ahli, guru dan tutor BIPA, serta pelajar BIPA.

Dalam penelitian ini, peneliti berposisi sebagai instrumen kunci. Penelitian dilakukan terutama dalam pengumpulan data, dan peneliti menggunakan panduan wawancara, lembar pencatatan hasil observasi, dan lembar penilaian terhadap produk. Analisis data penelitian ini dilakukan secara bertahap. Data verbal yang berupa perilaku, ciri pelajar asing, dan pemetaan domain pembelajaran BIPA digunakan untuk mengembangkan rancangan bahan pembelajaran. Draft model perangkat pembelajaran tersebut dicek keabsahannya melalui triangulasi teori, metode, kelompok ahli, dan uji coba produk ke lapangan. Data yang berupa hasil triangulasi dan uji coba tersebut digunakan untuk revisi produk. Data tersebut secara keseluruhan dianalisis dengan menggunakan teknik analisis domain.

\section{Hasil Penelitian dan Pembahasan Kondisi Awal Pelajar BIPA}

Pelajar BIPA berasal dari berbagai negara, sehingga mereka memiliki latar belakang bahasa dan budaya yang berbeda-beda. Di samping itu, mereka secara keseluruhan juga memiliki perbedaan bahasa dan budaya dengan bahasa dan budaya Indonesia yang akan dipelajarinya. Hal itu berdampak pada pemilihan materi bahasa Indonesia yang akan diajarkan kepada mereka. Pemilihan materi yang tidak sesuai dapat menjadi penyebab kesulitan dan kebosanan pelajar asing dalam belajar.

Pelajar asing yang belajar BIPA memiliki tingkat kemampuan yang berbeda-beda. Mereka ada yang sudah belajar selama dua tahun di universitas asalnya, ada pula yang belum pernah belajar bahasa Indonesia sama sekali. Di antara mereka, ada beberapa pelajar asing yang sudah pernah ke Indonesia dan ada pula yang belum pernah ke Indonesia. Bagi mereka yang sudah pernah belajar bahasa Indonesia, materi belajarnya pun juga berbeda-beda, yakni ada yang memfokuskan pada belajar struktur bahasa lndonesia dan ada pula yang belajar keterampilan berbahasa Indonesia. Tujuan pelajar asing belajar BIPA adalah mereka ingin lancar berbahasa Indonesia dan mengenal budaya Indonesia dari dekat. Kelancaran berbahasa Indonesia tersebut diperlukan oleh mereka karena (a) mereka mengambil program tentang Indonesia di universitas asalnya, (b) mereka akan melakukan penelitian di Indonesia, (c) mereka akan bekerja di Indonesia, (d) mereka akan meneliti masalah bahasa Indonesia, dan (e) mereka akan tinggal di Indonesia dalam 
waktu lama. Gambaran tentang tujuan belajar BIPA tersebut berimplikasi pada penyiapan materi belajar yang sesuai dengan tujuan tersebut. Dengan demikian, materi pembelajaran BIPA ini memiliki kaitan yang erat dengan masalah pemenuhan kebutuhan pelajar asing.

\section{Materi Pembelajaran BIPA yang Diperlukan}

Materi bahasa yang dikembangkan dalam pembelajaran BIPA didasarkan pada tingkat kemampuan bahasa Indonesia pembelajarnya. Untuk tingkat pemula diberikan materi bahasa, antara lain kata sapaan, ungkapan keseharian sederhana, kalimat sederhana, kalimat aktif, kalimat pasif, kalimat negatif, preposisi, kata/kalimat tanya, kata bilangan, dan afiksasi (me(N)-, me(N)kan, me(N)-i, se-nya, di-, di-kan, di-i, ber-, ter-, dan pe(N)-). Untuk tingkat menengah diberikan materi bahasa, antara lain ungkapan dalam bahasa Indonesia, kalimat kompleks, kalimat aktif, kalimat pasif, kalimat negatif, kalimat transitif dan intransitif, preposisi, kalimat tanya, dan afiksasi (me(N)-, me(N)-kan, me(N)-i, se-nya, di-, di-kan, di-i, ber-, ter-, dan pe(N)-, pe(N)-an, per-an, ber-an, memper-kan, member-kan,). Adapun untuk tingkat lanjut, materi yang disajikan pada pokoknya hampir sama dengan materi untuk tingkat menengah, hanya tingkat kekompleksannya yang berbeda.

Untuk tingkat lanjut, penekanannya lebih pada pemahaman secara analitis terhadap materi bahasa. Kepada pelajar, selain diberikan materi-materi tersebut, banyak juga diberikan materi-materi analisis, yakni menganalisis kalimat salah dan membenarkannya serta mengubah pola kalimat tanpa mengubah maknanya. Materi menyimak dan wicara dikembangkan dengan menggunakan materi dialog, mulai dari dialog yang sangat sederhana (misalnya: salam) sampai dengan dialog yang sangat kompleks dan formal (misalnya: seminar). Materi dialog ini dalam praktik pembelajarannya sekaligus dimanfaatkan untuk materi pembelajaran menyimak. Dengan demikian materi pembelajaran menyimak dan wicara dikemas dalam satu wujud materi.

Selain materi yang berbentuk dialog, dalam pembelajaran menyimak, juga memanfaatkan wacana yang ada dalam kegiatan berbahasa seharihari, misalnya menyimak berita atau percakapan yang ada di televisi, radio, maupun percakapan sehari-hari. Materi-materi tersebut disajikan kepada pelajar sesuai dengan tingkat kemampuannya. Untuk tingkat pemula, disajikan materi-materi dialog keseharian sederhana dalam bahasa Indonesia. Untuk tingkat menengah diberikan materi dialog keseharian yang agak kompleks dan dialog-dialog formal yang sederhana. Adapun untuk tingkat lanjut diberikan materi dialog yang lebih kompleks, baik berkaitan dengan topik keseharian maupun topik formal.

Pengembangan materi membaca dan menulis disesuaikan dengan tingkat kemampuan pelajarnya. Untuk tingkat pemula diberikan bacaan dalam bahasa Indonesia yang sederhana, untuk tingkat menengah diberikan bacaan dalam bahasa Indonesia yang agak kompleks, dan untuk tingkat lanjut diberikan 
bacaan bahasa Indonesia yang kompleks. Materi-materi bacaan sederhana banyak diambil dari bacaan yang ada di majalah anak, bacaan yang ada pada buku bahasa Indonesia di sekolah dasar, atau bacaan yang disusun sendiri oleh pengajar. Adapun bacaan untuk tingkat menengah dan tingkat lanjut dapat menggunakan bacaan yang ada di surat kabar atau pun majalah. Adapun untuk materi menulis dimulai dari menulis kalimat, menulis topik sederhana tentang pengalamannya atau apa yang telah dilakukannya sampai dengan menulis makalah untuk diseminarkan dalam seminar di kelasnya.

Pengembangan materi budaya diserahkan pada pengajarnya. Pokokpokok materi yang perlu diberikan pada pelajar adalah tentang bagaimana hidup dalam keluarga, berteman, bermasyarakat, dan sopan-santun dalam pergaulan. Hal yang prinsip dalam pemberian materi budaya ini adalah membekali pelajar BIPA agar mampu berbahasa Indonesia sesuai dengan situasi dan kondisi. Tahapan materi yang disajikan dalam pembelajaran meliputi (1) penyajian dialog, (2) penyajian kata-kata sulit yang ada dalam dialog dan latihan membuat kalimat dengan kata-kata sulit tersebut, (3) latihan merespon pernyataan-pernyataan lepas dan pertanyaan-pertanyaan yang ada dalam dialog, (4) mengembangkan kreativitas dengan cara membuat pertanyaan atau pernyataan sesuai dengan topik yang dikehendaki dalam soal, (5) teks bacaan dengan kata-kata yang tingkat kesulitannya hampir sama dengan kata-kata yang ada dalam dialog, (6) pertanyaan bacaan dan latihan tentang isi bacaan, (7) mengubah pola kalimat dari kalimat yang ada dalam bacaan, dan (8) menulis ringkasan/kesan/ kritik/tanggapan terhadap isi bacaan.

\section{Pendek atan yang Digunakan dalam Pembelajaran}

Dari hasil pengamatan dan wawancara, dapat diketahui bahwa pengajar BIPA dalam membelajarkan pelajar asing di kelas lebih menekankan pada penggunaan bahasa daripada menjelaskan tata bahasa. Guru dalam pembelajaran lebih banyak memfungsikan dirinya sebagai mitra bicara bagi siswanya. Dalam hal ini, guru memberikan latihan pemakaian bahasa untuk berkomunikasi. Untuk itu, materi pembelajaran diwujudkan dalam bentuk keterampilan berbahasa.

Dalam pembelajaran BIPA, bahasa Indonesia ditempatkan sebagai alat komunikasi, bukan sebagai materi bahasa yang dihafalkan atau dianalisis. Bahasa Indonesia difungsikan sebagai alat komunikasi baik secara lisan maupun tulis. Oleh karena itu, dalam pembelajaran BIPA, tujuan yang ingin dicapai adalah kemampuan pelajar untuk berkomunikasi dengan menggunakan bahasa Indonesia yang dipelajarinya. Dengan demikian, pelajar diharapkan dapat memiliki kemampuan komunikatif. Sejalan dengan harapan tersebut, dalam pembelajaran BIPA, ditekankan kepada pelajar BIPA tentang (1) pengetahuan tentang bentuk bahasa yang mungkin dikatakan, (2) pengetahuan tentang kata yang dapat dituturkan dan dapat dipahami oleh pendengar, (3) pengetahuan tentang kata yang sesuai dan wajar menurut 
konteksnya, dan (4) pengetahuan tentang kata yang pernah diujarkan orang. Dengan penguasaan keempat hal tersebut, seseorang akan dapat berbahasa secara berterima.

Berdasarkan pada perolehan hasil belajar yang ditargetkan, dalam pengajaran BIPA, ancangan yang dipilih adalah ancangan komunikatif. Seperti halnya ancangan lain, ancangan komunikatif memiliki asumsi tentang hakikat bahasa dan belajar bahasa. Hal ini sejalan dengan pendapat Richard dan Rodgers (1986) yang menjelaskan bahwa asumsi ancangan komunikatif tentang hakikat bahasa adalah

1. bahasa merupakan sistem dalam pengungkapan makna,

2. bahasa adalah alat bagi manusia untuk berkomunikasi dan berinteraksi,

3. struktur bahasa mencerminkan fungsi penggunaannya dan fungsi komunikatifnya, dan

4. unit utama bahasa bukan hanya berupa unit gramatikal melainkan juga fungsi dan makna komunikasi.

Lebih lanjut, Richard dan Rodgers (1986) menjelaskan bahwa dalam kaitannya dengan belajar bahasa ancangan komunikatif mengajukan tiga prinsip, yakni

1. belajar bahasa terjadi apabila kegiatan itu berlangsung dalam suatu komunikasi yang nyata,

2. dalam kegiatan komunikasi seperti ini, bahasa nyata-nyata digunakan, dan

3. penggunaan bahasa yang nyata inilah yang bagi pelajar bermakna sekaligus fungsional.

Selain itu, keterkaitannya dengan ancangan komunikatif, Van Eck (dalam Machmoed 1990) menjelaskan bahwa pengajaran bahasa dengan ancangan komunikatif memerlukan komponen yang ditentukan dengan tujuan pengajaran bahasa, yakni

1. situasi yang melatarbelakangi penggunaan bahasa, meliputi peranan pembicara, latar, dan pokok bahasan yang dibicarakan;

2. kegiatan kebahasaan apa yang kelak perlu dilaksanakan oleh pelajar;

3. fungsi bahasa yang akan dilaksanakan pelajar dalam penggunaan bahasanya kelak;

4. apa yang dapat dilaksanakan pelajar terhadap setiap pokok bahasan;

5. nosi umum apa yang akan dapat ditangani oleh pelajar;

6. konsep khusus apa yang ditangani oleh pelajar kelak;

7. bentuk bahasa apa yang dipakai oleh pelajar; dan

8. tingkat keterampilan yang kelak dapat dimanifestasikan oleh pelajar.

Program pengajaran dengan tujuan tersebut memerlukan kegiatan dan 
proses belajar yang bervariasi, yang dapat mcmbantu pelajar mencapai perangkat tujuan tersebut.

Menurut para pengajar BIPA, penerapan ancangan komunikatif dalam pembelajaran BIPA memiliki banyak keuntungan, yakni

1. bahan-bahan otentik tidak terlalu sulit diperoleh, misalnya dari brosur, $\mathrm{TV}$, suratkabar, dan lain-lain;

2. kegiatan di kelas dapat dihubungkan dengan tugas di luar kelas atau tugas terstruktur yang lain;

3. pemahaman dan pengalaman dalam hubungan bahasa dan budaya menjadi lebih konkret; dan

4. masalah gegar budaya yang dialami pelajar dapat diatasi dengan membina hubungan yang baik (rapport) antara pelajar, pengajar, dan masyarakat.

Dengan situasi yang demikian ini, prinsip komunikasi di kelas atau pun di luar kelas dapat diterapkan dalam keterpaduan keterampilan dengan adanya kesenjangan informasi, transfer informasi, adanya umpan balik, dan negosiasi serta koreksi pada informasi.

\section{TeKnik Pembelajaran BIPA yang Diharapkan}

Dalam kaitannya dengan teknik pembelajaran BIPA, ada beberapa hal yang dikaji, yaitu (1) teknik penyampaian materi, (2) teknik menghadapi pelajar, dan (3) teknik penciptaan suasana belajar. Teknik penyampaian materi dibagi dalam tiga tahap, yakni teknik membuka pelajaran, teknik menyampaikan materi baru, dan teknik menutup pelajaran. Ada sejumlah teknik yang dilakukan guru dalam memulai pelajaran di kelas, di antaranya adalah (1) memberi salam, (2) menanyakan keadaan/situasi di tempat tinggal, (3) menanyakan perasaannya, (4) menanyakan kegiatan yang telah dilakukannya, (5) menanyakan tentang waktu (tidur, mimpi, bangun, berangkat sekolah, dsb.), (6) bercerita apa yang telah dilakukan (guru), (7) bertanya dengan menggunakan kata-kata atau kalimat yang telah diberikan hari sebelumnya, (8) menanyakan sesuatu yang dibawa atau yang ada pada pelajar, (9) merespon pernyataan/ pertanyaan yang sejak awal disampaikan pelajar, (10) menjelaskan hal-hal apa yang akan dilakukan hari itu atau selanjutnya.

Teknik tersebut banyak digunakan guru dalam memulai pelajaran di kelas. Teknik tersebut bertujuan untuk menciptakan suasana yang akrab dan hangat sebelum memulai pelajaran. Selain itu, teknik semacam itu dapat dimanfaatkan untuk melatih pelajar berani berkomunikasi dengan menggunakan bahasa Indonesia yang dipelajarinya. Dengan demikian, guru dapat mengetahui seberapa banyak kata yang telah dikuasai oleh pelajar, pada masalah apa dia mengalami kesulitan, hal-hal apa yang perlu diulangi. Keuntungan lain yang dapat diperoleh dari teknik memulai pelajaran dengan cara seperti ini adalah guru dapat memberikan tambahan kata-kata yang sesuai dengan kebutuhan pelajar saat itu, dan kata-kata yang demikian 
inilah yang sebenarnya fungsional bagi pelajar. Teknik yang digunakan oleh guru dalam menyajikan materi pada dasarnya menggunakan teknik celup total. Guru berusaha sedapat mungkin tidak menggunakan bahasa Inggris. Berbagai cara yang digunakan untuk penyajian materi tersebut di antaranya tanya jawab, pelatihan, penugasan, demonstrasi, pemberian konsultasi baik kelompok maupun individual, tutorial, penubian (drill), dan koreksi.

Di dalam pelaksanaan teknik celup ini, guru berusaha semaksimal mungkin untuk tidak menggunakan bahasa Inggris kepada pelajar. Demikian juga pelajar, dianjurkan untuk selalu menggunakan bahasa Indonesia. Jika mereka sekali diberi kesempatan untuk berbahasa Inggris, maka mereka akan selalu meminta penjelasan dalam bahasa Inggris. Hal ini sesuai dengan saran Wolff (1988) yang menyarankan bahwa bahwa pengajar BIPA perlu memperhatikan teknik berikut dalam mengajarkan BIPA, yakni

1. berbicaralah kepada pelajar dengan bahasa Indonesia,

2. pakailah kata-kata, bentukan-bentukan, kalimat-kalimat dan tata bahasa yang sudah diketahui pelajar,

3. janganlah memberikan peluang dan keleluasaan kepada pembelajar untuk berbahasa Inggris, sekalipun mereka belum bisa menyampaikan maksudnya dengan bahasa Indonesia yang baik,

4. berbicaralah secara wajar,

5. apabila pelajar mengucapkan kalimat yang salah, katakanlah kalimat yang dimaksudkan dengan betul, kemudian suruhlah mereka mengulanginya,

6. kesalahan yang dilakukan oleh pelajar hendaklah disikapi sebagai kesalahan bersama,

7. penjelasan tentang kata atau istilah hendaknya didasarkan pada aspek sosiosemantis dengan mengefektifkan penggunaan contoh-contoh, dan

8. apabila pelajar menemui kesulitan dalam pelatihan (ucapan dan penangkapan) kalimat panjang, potonglah kalimat tersebut dalam satuan bermakna yang dimulai dari ujung kalimat.

Teknik penyajian materi tidak saja dilakukan di dalam kelas, tetapi juga dilakukan di luar kelas. Teknik yang ditempuh dalam penyajian materi melalui kegiatan di luar kelas ini di antaranya melalui kegiatan tugas luar (ke bank, ke studio foto, ke pasar), bertamu, wawancara dengan mahasiswa Indonesia,kunjungan ke tempat-tempat wisata, melihat benda-benda kerajinan (seperti wayang, keramik, topeng), melihat pertunjukkan, menyaksikan upacara adat (pernikahan, kematian), dan sebagainya.

Cara yang demikian itu sesuai dengan pendapat yang dikemukakan oleh Surajaya (1995) yang mengemukakan kiat-kiat yang dapat dilakukan dalam pengajaran BIPA, yakni

1. kiat kuliah,

2. kiat penjelasan dengan contoh benda budaya,

3. kiat demonstrasi dan partisipasi aktif, 
4. kiat peninjauan ke lapangan atau ekskursi,

5. kiat majalah dinding,

6. kiat tari dan nyanyi,

7. kiat permainan simulasi,

8. kiat informan penutur asli,

9. kiat video-tape,

10. kiat audio-motorunits,

11. kiat identifikasi secara kultural perilaku umum,

12. kiat identifikasi konotasi kultural,

13. kiat minimalisasi persepsi yang bersifat stereotip, dan

14. kiat memanfaatkan bacaan otentik.

\section{Pelaksanaan Evaluasi Pembelajaran BIPA}

Dalam hasil wawancara dengan para tutor BIPA, diperoleh gambaran bahwa evaluasi pengajaran BIPA dilakukan dengan maksud untuk mengetahui kemajuan belajar pelajar asing. Pelaksanaan evaluasi tidak selalu diwujudkan dalam bentuk tes formal, tetapi dilakukan dalam bentuk wawancara dan tanya jawab selama proses pembelajaran. Proses evaluasi yang demikian ini dilakukan secara terus-menerus untuk memantau perkembangan kemahiran berbahasa pelajar asing.

Dari segi waktu pelaksanaannya, evaluasi pembelajaran BIPA dibedakan ke dalam evaluasi harian, evaluasi mingguan (satu minggu dan dua minggu), evaluasi tengah program, dan evaluasi akhir program. Setiap jenis evaluasi tersebut memiliki tujuan, wujud, dan fungsi yang berbeda-beda. Evaluasi harian adalah evaluasi yang dilaksanakan setiap saat atau setelah kegiatan belajar-mengajar dilaksanakan. Tujuan evaluasi tersebut adalah untuk membelajarkan pelajar agar terpacu untuk belajar. Evaluasi semacam ini dilaksanakan dengan cara memberikan tugas, pekerjaan di kelas, dan pekerjaan rumah yang harus diselesaikan oleh pelajar. Pada prinsipnya evaluasi harian ini digunakan sebagai alat belajar-mengajar. Dengan evaluasi harian ini, pengajar segera mengetahui kelemahan pelajar baik berkaitan dengan masalah pemahaman kata, struktur kalimat, pelafalan, pembentukan kata, maupun penggunaan kata.

Evaluasi mingguan adalah evaluasi yang dilaksanakan pada setiap akhir minggu pelajaran. Materi evaluasi diambil dari materi pelajaran selama satu minggu pada minggu tersebut. Tujuan dilaksanakannya evaluasi ini adalah untuk mengetahui tingkat penguasaan pelajar terhadap materi yang telah disajikan selama satu minggu pelajaran. Hasil evaluasi ini tidak dimanfaatkan untuk kepentingan pemberian nilai tetapi lebih mengarah untuk kepentingan diagnosis dan remedial. Hasil koreksi terhadap jawaban evaluasi diberikan kembali kepada pelajar pada hari pertama minggu berikutnya. Hasil koreksian tersebut dibahas bersama di dalam kelas. Dalam pembahasan ini, pengajar memberikan penjelasan-penjelasan ulang materi yang kurang dikuasai oleh pelajar. Demikian evaluasi ini dilaksanakan terus-menerus pada setiap akhir 
minggu pelajaran, kecuali jika dalam minggu tersebut dilaksanakan evaluasi dua mingguan atau evaluasi tengah pelaksanaan program.

Evaluasi dua mingguan adalah evaluasi yang dilaksanakan setiap dua minggu pelajaran. Evaluasi ini bertujuan ganda, yakni selain untuk kepentingan diagnosis dan remedial, melihat perkembangan kemampuan bahasa pelajar, juga untuk memberikan pertimbangan dalam memberikan nilai akhir untuk kepentingan administrasi. Materi yang diberikan dalam evaluasi dua mingguan ini terbatas pada materi selama dua minggu pelajaran. Pelaksanaan evaluasi dua mingguan ini adalah pada hari terakhir pelajaran pada setiap dua minggu dan waktunya selama dua jam, yakni jam pertama dan jam kedua. Setelah pelaksanaan evaluasi, jam berikutnya tidak ada pelajaran di kelas, tetapi diganti dengan kunjungan ke tempat wisata atau ke tempat pembuatan kerajinan. Hasil evaluasi dua mingguan ini sangat penting untuk memberikan laporan perkembangan kemampuan bahasa Indonesia pelajar dan untuk memberikan pertimbangan pemberian nilai akhir.

Evaluasi tengah program dilaksanakan jika program telah berlangsung lebih kurang separuh dari lama program yang telah ditentukan. Evaluasi ini merupakan evaluasi besar bagi pelajar. Materi evaluasinya meliputi materi sejak awal perkuliahan sampai materi yang diberikan sehari sebelum evaluasi tersebut dilaksanakan. Tujuan evaluasi ini lebih mengarah pada kepentingan pemberian nilai akhir pelajar. Hal ini bukan berarti bahwa jika ditemukan ada kekurangan pada pelajar dibiarkan saja, tetapi jika ada kelemahan-kelamahan tersebut guru memberikan layanan secara individual. Program semacam ini dalam program pengajaran BIPA dikenal dengan istilah konsultasi dan tutorial. Yang menangani kegiatan konsultasi ini bukan hanya guru yang mengajar di kelas, tetapi juga para tutor lainnya. Evaluasi akhir program adalah evaluasi yang dilaksanakan pada hari terakhir suatu program. Materi evaluasi akhir program ini ditentukan berdasarkan kesepakatan antara pengajar (pembuat tes) dengan para pelajar (misalnya: mulai babXsampai dengan babY). Hasilevaluasiakhir programini dimanfaatkanuntuk memberikan nilai bagi pelajar. Di samping itu hasil tersebut dimanfaatkan pula untuk melihat tingkat perkembangan hasil belajar dan mengetahui keefektifan pelaksanaan program.

Berdasarkan bentuknya, evaluasi yang dilaksanakan dalam pengajaran BIPA dapat dibedakan menjadi dua, yakni evaluasi objektif dan subjektif. Evaluasi objektif digunakan untuk mengevaluasi kemampuan tata bahasa, pemahaman makna kata dan penggunaannya dalam kalimat, kemampuan menerjemahkan, dan pemahaman bacaan. Adapun evaluasi subjektif digunakan untuk mengevaluasi kemampuan produksi pelajar. Evaluasi bentuk subjektif tersebut berupa tugas mengarang di rumah, membuat komposisi dua atau tiga paragraf dalam waktu yang terkontrol, membuat makalah kecil untuk diseminarkan, menyusun teks dialog dengan topik yang telah ditentukan, dan sebagainya. 
Selain itu, atas dasar caranya, evaluasi pengajaran BIPA dilaksanakan dalam tiga cara, yaitu evaluasi tulis, evaluasi secara lisan, dan evaluasi dalam bentuk seminar. Evaluasi tulis digunakan untuk mengevaluasi penguasaan pelajar terhadap materi bahasa yang telah diajarkan, misalnya penguasaan tata bahasa, kosakata, pemahaman bacaan, terjemahan, dan kemampuan menulis karangan. Adapun evaluasi secara lisan digunakan untuk mengevaluasi kemampuan komunikasi pelajar. Dalam hal ini kemampuan melafalkan kata, kemampuan menggunakan bahasa secara spontan, kemampuan memilih dan menggunakan kata-kata yang tepat, dan kelancaran dan kecermatan berbahasa. Adapun evaluasi dengan cara seminar dilaksanakan pada tingkat menengah dan tingkat lanjut. Evaluasi tersebut di samping untuk memberikan nilai, juga untuk memacu pelajar berani tampil secara formal dengan menggunakan bahasa Indonesia.

\section{Rancangan Bahan untuk Penyusunan Materi Ajar BIPA}

Berdasarkan hasil analisis kebutuhan belajar, dikemukakan bahwa pelajar asing yang belajar BIPA adalah pelajar dewasa. Sejalan dengan kondisi pelajar asing tersebut, topik yang dipilih untuk materi ajar BIPA adalah topik yang berkaitan dengan minat dan kebutuhan belajar orang dewasa. Topik tersebut di antaranya adalah salam, perkenalan, wisata, kegemaran, kerajinan, suratmenyurat, pesta, rekreasi, dan sebagainya. Mereka juga menyukai topik-topik aktual seperti masalah lingkungan, hubungan antarmanusia, energi, peristiwa dunia, dan sebagainya.

Pelajar asing belajar BIPA karena mereka memiliki beberapa tujuan, di antaranya (1) untuk berkomunikasi keseharian dengan penutur bahasa Indonesia (tujuan umum), dan (2) untuk menggali kebudayaan Indonesia dengan segala aspeknya (tujuan khusus). Tujuan yang pertama, penekanannya pada penguasaan bahasa sehari-hari yang dapat dipakai untuk kepentingan praktis, seperti menyapa, menawar, menolak, mempersilakan, mengucapkan terima kasih, minta izin, mengajak, mengeluh, memuji, memperkenalkan, berpamitan, dan sebagainya. Ciri khas bahasa untuk kepentingan ini adalah lebih sering (1) menggunakan bentuk-bentuk kata yang tidak formal, (2) menggunakan kosakata tidak baku, (3) menghilangkan imbuhan, dan (4) menggunakan susunan kalimat yang sederhana. Adapun ciri bahasa untuk tujuan kedua adalah penggunaan (1) bentuk kata baku, (2) kosakata teknis, (3) imbuhan secara lengkap, (4) kaidah penulisan yang benar, dan (5) susunan kalimat yang baku.

Pengembangan dan penataan materi perlu disesuaikan dengan kebutuhan dan tingkat kemampuan pelajarnya. Karena itu, pengelolaan materi pembelajaran BIPA perlu memperhatikan tiga hal, yakni (1) orientasi materi hendaknya diarahkan dan dititikberatkan pada materi yang (a) dapat dipakai dan berpotensi untuk dilatihkan, (b) benar-benar ada dan dipakai dalam komunikasi nyata di masyarakat, dan (c) mampu mengembangkan kompetensi untuk berlatih dan memahami pola serta mampu mengembangkan 
pemahaman bahasa Indonesia melalui bentuk-bentuk percakapan/dialog yang situasional-kontekstual; (2) rentangan dan penataan materi harus diupayakan pada materi-materi yang mengacu pada aspek-aspek yang menentukan bagaimana bahasa Indonesia digunakan, yakni aspek-aspek. (a) kosa kata, (b) pola kalimat, (c) wacana/percakapan, (d) lafal/ucapan dan intonasi, dan (e) pengolahan ide; dan (3) materi pembelajaran perlu ditata berdasarkan unit-unit satuan ujaran yang komunikatif secara terpadu.

Untuk memenuhi kebutuhan belajar pelajar asing dalam belajar BIPA, pembelajaran BIPA hendaknya berorientasi pada pelajar BIPA sebagai pusat (learner centered). Oleh karena itu, materi pembelajaran harus dipilihkan materi yang fungsional. Untuk itu, materi BIPA hendaknya dipilih materi yang memiliki ruang lingkup atau jangkauan pada aspek BI, yakni (1) aspek jangkauan orientasi dan tujuan pembelajaran, yakni untuk kepentingan apakah pembelajar tertarik dengan BIPA: apakah untuk komunikasi semata, penelitian, penerjemahan, ataukah untuk kepentingan-kepentingan khusus yang berkenaan dengan profesi atau tugas-tugasnya, (2) aspek kepraktisan dan kekomunikatifan secara faktual, bukan berorientasi pada BI yang seharusnya (berdasarkan tata bahasa), (3) aspek kemudahan, mengacu pada kuantitas dan produktivitas yang memfasilitasi kreativitas berbahasa Indonesia, (4) aspek perkembangan BI, baik dalam satuan teori dan tata bahasa maupun isi materialnya, (5) aspek fleksibilitas, (6) aspek kebermaknaan, dan (7) aspek keragaman.

Salah satu kriteria pemilihan materi pembelajaran BIPA adalah kesesuaian antara tingkat kemampuan pelajar, tujuan yang ingin dicapai, dan minat atau kesukaan pelajar. Berdasarkan kriteria tersebul, untuk merencanakan materi pembelajaran, sekurang-kurangnya ada dua langkah pokok yang perlu dilakukan, yakni (1) mengaitkan pengembangan materi dengan karakteristik pelajar, tujuan pembelajaran, dan materi belajar; dan (2) mengaitkan kegiatan pada langkah pertama dengan kegiatan belajar-mengajar.

Beberapa hal yang perlu diperhatikan dalam pengembangan materi pembelajaran BIPA diantaranya adalah (1) pengembangan materi pembelajaran BIPA sedapat mungkin dilengkapi dengan pre-reading (khususnya pengenalan ucapan, intonasi, dan aksen); (2) formulasi materi pembelajaran BIPA harus mengacu pada (a) target tujuan dan isi pembelajaran serta cakupan perilaku yang spesifik, (b) target kompetensi yang hendak dikondisikan selanjutnya, dan (c) bidang, minat pelajar, dan alokasi pembelajaran yang tersedia; (3) format hasil pengembangan materi pembelajaran BIPA, sekurang-kurangnya mengandung aspek-aspek berikut, yakni (a) penyajian dialog, (b) penyajian kata-kata sulit yang ada dalam dialog dan latihan membuat kalimat dengan kata-kata sulit tersebut, (c) latihan merespon pernyataan-pernyataan lepas dan pertanyaan-pertanyaan yang ada dalam dialog, (d) mengembangkan kreativitas dengan cara membuat pertanyaan atau pernyataan sesuai dengan topik yang dikehendaki dalam soal, (e) teks bacaan dengan kata-kata yang tingkat kesulitannya hampir sama dengan kata yang ada dalam dialog, (f) 
pertanyaan bacaan dan latihan tentang isi bacaan, (g) mengubah pola kalimat dari kalimat-kalimat yang ada dalam bacaan, dan (h) menulis ringkasan/ kesan/ kritik/tanggapan terhadap isi bacaan.

\section{SiMPULAN DAN SARAN}

Hasil penelitian ini menunjukkan bahwa pelajar asing yang belajar bahasa Indonesia memiliki latar belakang bahasa dan budaya berbeda-beda, tujuan belajar dan tingkat kemampuan yang beragam, dan bidang keahlian yang beragam. Untuk itu, disarankan kepada pengelola dan pengajar BIPA agar dalam pengelolaan pembelajaran BIPA, faktor diri pelajar mendapat perhatian secara sungguh-sungguh. Dalam hal ini, pembelajaran BIPA hendaknya berpusat pada kebutuhan pelajar.

Materi ajar yang dibutuhkan oleh pelajar BIPA sangat bergantung pada tujuan belajar atau kebuluhan belajar pelajar asing. Oleh karena itu, disarankan kepada pengelola dan pengajar BIPA, dalam memilih materi BIPA hendaknya memilih materi bacaan dengan topik yang lebih variatif sehingga dapat memenuhi kebutuhan belajar pelajar asing. Di samping itu, materi belajar yang dipilih hendaknya juga memenuhi materi keterampilan berbahasa, tata bahasa, pelafalan, dan budaya.

Pada umumnya, pendekatan yang diminati dan sesuai untuk pembelajaran BIPA adalah pendekatan komunikatif. Oleh karena itu, disarankan kepada para pengelola dan pengajar BIPA agar memanfaatkan pendekatan komunikatif dalam pembelajaran dengan berupaya mengembangkan berbagai strategi untuk menjadikan kegiatan pembelajaran lebih menarik.

Evaluasi dalam pembelajaran BIPA dilaksanakan dengan teknik tes dan nontes. Untuk itu, disarankan kepada pengajar BIPA agar dalam kegiatan pembelajaran BIPA selalu memperhatikan perilaku belajar dan perkembangan perolehan belajar pelajarnya. Dengan demikian, pengajar dapat memberikan nilai secara lebih objektif kepada pelajarnya.

\section{DAFTAR ACUAN}

Brown, H. Douglas. 1987. Principles of Language Learning and Teaching. New Jersey: Prentice Hall, Inc.

Collins, James T. 1993. Kemajuan Penelitian Bahasa Indonesia di Amerika Serikat. Makalah Kongres Bahasa Indonesia VI Tahun 1993 di Jakarta.

Corder, S. 1978. "Language-Learner Language" dalam Richard, J. Understanding Second and Foreign Language Learning. Rowley: Newbury House Publisher, Inc.

Dardjowidjojo, Soenjono. 1993. Peningkatan Peran Pengajaran Bahasa Indonesia sebagai Bahasa Asing. Makalah Kongres Bahasa Indonesia VI Tahun 1993 di Jakarta.

Dick, W. dan L. Carey. 1978. The Systematic Design on Instructional. Illinois: Scot, Foreman and Company.

Dulay, H., M. Burt dan S. Krashen. 1982. Language Two. Oxford: Oxford University Press.

Ellis, Rod. 1986. Understanding Second Language Acquisition. Oxford: Oxford University Press.

Gass, Susan M., et al. 2002. Pedagogical Norms for Second and Foreign Language Learning and Teaching. Philadelphia: John Benjamins Publishing Company.

Hoed, Benny H.. 1995. Kerjasama Antarpemerintah dan Antarlembaga untuk Pengembangan BIPA. Makalah Kongres BIPA 1995 Fakultas Sastra Universitas Indonesia Jakarta. 
Hutchinson, Tom dan Alan Waters. 1989. English for Special Purposes: a Learning-Centered Approach. Cambridge: Cambridge University Press.

Johnson, K. 1982. Communicative Language Teaching. London: Cambridge University Press.

Krashen, S. dan Tracy D. Terrell. 1985. The Natural Approach: Language Acquisition in the Classroom. New York: Pergamon.

Long, Michael, et al. 1991. An Introduction to Second Language Research. London: Longman.

Machmoed, Zaini. 1990. "Proses dan Evaluasi Pembelajaran dan Pengajaran Kompetensi Komunikatif" dalam Warta Scientia, No. 49. Th. XVIII, April 1990.

Magnan, Sally Sieloff dan Joel Walz. 2002. “Pedagogical Norm, Development of Concept and Illustrations From French" dalam Susan M Gass, et al. 2002. Pedagogical Norms for Second and Foreign Language Learning and Teaching. Philadelphia: John Benjamins Publishing Company.

Munby, John. 1980. Communicative Syllabus Design. Cambridge: Cambridge University Press.

Richards, J.C. dan T.S. Rodgers. 1986. Approaches and Methods in Language Teaching. Cambridge: Cambridge University Press.

Robinson, Pauline. 1980. English for Specific Pusposes. Oxford: Pergamon Press.

Soewandi, A.M. 1994. Pengajaran Bahasa Indonesia sebagai Bahasa Asing: Tujuan, Pendekatan, Bahan Ajar, dan Pengurutannya. KIPBIPA UKSW: Salatiga.

Sofyan, Lia Angela S. 1983. "Pengajaran ESP pada Tingkat Perguruan Tinggi”, dalam Linguistik Indonesia, Tahun No. 1, Januari 1983.

Spradley, James P. 1979. The Ethnographic Interview. New York: Holt, Rinehart and Winston.

Sugino, S. 1995. Pendekatan Komunikatif-Integratif-Tematis dalam Pengembangan Bahan dan Metodologi Pengajaran BIPA di Indonesia. Kongres BIPA 1995 Fakultas Sastra Universitas Indonesia Jakarta.

Suyitno, Imam, et al. 1996. Pengajaran Bahasa Indonesia untuk Penutur Asing di Malang. Hasil Penelitian yang Dibiayai OPF IKTP Malang. Malang: IKIP Malang.

Suyitno, Imam. 2000. Pengembangan Materi Ajar Bahasa Indonesia untuk Penutur Asing. Malang: Jurusan Sastra Indonesia FS UM.

Wolff, John. 1991. "The SEASSI 1991" dalam Bulletin for Teachers of Southeast Asian Languages, Vol. V, No. 2, December 1991.

Wojowasito, S. 1976. Perkembangan Ilmu Bahasa (Linguistik) Abad 20. Bandung: Shinta Dharma. 